\title{
Shading Responses of Cherimoya Leaf Chlorophyll Content, Leaf Morphology, Shoot Growth, Leaf Gas Exchange and Fruit Production under Plastic House Conditions
}

\author{
Hirokazu Higuchi, John Y. Yonemoto, ${ }^{*, 1}$ Naoki UtsunOMIYA** \\ and Tetsuo SAKURATANI \\ Laboratory of Tropical Agriculture, Graduate School of Agriculture, Kyoto University, \\ Kyoto 606-8502, Japan \\ * Wakayama Fruit Tree Experiment Station, Kibi, Arida, Wakayama 643-0022, Japan \\ ** Faculty of Agriculture, Kinki University, Nara 631-8505, Japan \\ ${ }^{1}$ Present address: Department of Technical Development and Assistance, Experiment Station for \\ Primary Industry in Mountainous Regions, Kozagawa, Higashimuro, Wakayama 649-4222, Japan
}

(Received February 19, 2001)

\begin{abstract}
Heat stress damages under plastic house conditions in summer have caused low productivity of cherimoya (Annona cherimola Mill.). Six-year-old 'Big Sister' cherimoya trees were grown at 3 different shading levels under plastic house conditions to examine if the shadings improve cherimoya production. The plastic house was divided into 3 sections : regular plastic house condition as a light shading, middle shading condition which was provided by a combination of the plastic film of the house and shade cloth, and deep shading condition produced by the plastic film with two sheets of the shade cloth. Shoot length, shoot diameter, leaf number, and total leaf area reduced as shade increased, but inter-node length and single-leaf area increased. Leaf chlorophyll content increased at deep shading condition. Leaves at light and middle shading performed higher $\mathrm{CO}_{2}$ assimilation rate $\left(A_{\mathrm{C}}\right)$ with higher stomatal conductance. Under high light, high leaf temperature caused high leaf vapor pressure deficit, resulting in a reduction of gas exchange rate. Throughout the daytime, $A_{\mathrm{C}}$ at light shading was maintained at a higher level than the other conditions except during midday, when stomatal conductance and leaf water potential were lowered. Under deeper shading conditions, fruit weight and quality were decreased and the harvest was delayed. Heavy shade using shade cloth under plastic house conditions appeared to detrimental to cherimoya production. A shading of 50-70\% sunlight was thought to be adequate to obtain optimal light environment for cherimoya cultivation.
\end{abstract}

Keywords : fruit production, growth, light intensity, plastic house, shade

\section{INTRODUCTION}

Cherimoya production has been expanded in warm temperate zones, however, its introduction into monsoon Asia has not been successful (George and Nissen, 1992); this is likely due to the warm summer climate being unfavorable for cherimoya cultivation. Higuchi et al. (1999) suggested that high temperatures and strong light intensities limited growth and reduced photosynthetic function. Stomatal closure was one of the important factors that decreased

Corresponding author : Hirokazu Higuchi, fax : +81-75-753-6352, e-mail : higuchi@ kais.kyoto-u.ac.jp 
cherimoya assimilation at warm and dry environment. Stomatal sensitivity at low relative humidity could reduce the $\mathrm{CO}_{2}$ assimilation rate. Such drought and high temperature conditions tend to raise leaf-to-air vapor pressure deficit, which is lessened by decreasing leaf temperature; thus, reducing the leaf temperature by shading may improve $\mathrm{CO}_{2}$ assimilation.

Japanese commercial orchards of cherimoya usually adopt plastic house culture. The plastic house is to protect from frost damages during winter, however, it causes high temperatures during summer. Sunburn of leaves and stems, less flowering, and reduction in fruit growth were often observed in cherimoya at high temperatures (Higuchi et al., 1998b). A heat damage, which is associated with high light, might be reduced by shading. Besides, cherimoya is tolerant to shaded conditions; Utsunomiya and Higuchi (1996) compared young cherimoya seedlings to other Annona seedlings such as sugar apple and soursop and noted that the chlorophyll content of cherimoya leaves were less affected by shading and that $\mathrm{CO}_{2}$ assimilation rate $\left(A_{\mathrm{C}}\right)$ reduction under shading conditions was less than other Annona leaves. These responses of cherimoya were similar to mangosteen, a shade tolerant tropical fruit tree (Wiebel et al., 1994). In a consideration of shade-tolerance and heat-sensitivity of cherimoya, shading could be beneficial for the production, if the effects of shading on reduction of temperature compensate the detrimental effects on $\mathrm{CO}_{2}$ assimilation. The plastic film of the house itself plays a role to reduce light intensity. Therefore, additional shading on a plastic house, which is indispensable to cherimoya cultivation in Japan, must be discussed. The influence of shade on cherimoya tree has not been studied under plastic house conditions in commercial fields.

The objective of this study was to determine the optimal level of shading for cherimoya production based on. photosynthetic rate, leaf temperature, shoot and leaf morphological acclimation, and fruit production at developmental shading levels under plastic film orchard systems.

\section{MATERIALS AND METHODS}

Plant materials and growth conditions. Six-year-old grafted 'Big Sister' cherimoya trees were grown under plastic house condition in an orchard of Wakayama Fruit Tree Experiment Station $\left(34^{\circ} 05^{\prime}\right.$ N.) in Japan. In September 1995 , the house was pitched with a new film which was made of $0.1 \mathrm{~mm}$-thick polyvinyl chloride (PVC). On April 17, 1996, the trees were subjected to 3 levels of artificial shade conditions. The plastic house $(6 \mathrm{~m} \times 30 \mathrm{~m})$ was divided into 3 sections by aluminum-coated polyethylene fabric (410ME, Daiokasei Co. Ltd., Tokyo Japan) partitions. Each shade treatment had 4 trees planted at $2 \mathrm{~m}$ intervals. The average tree height was $3 \mathrm{~m}$. Inside the plastic house, sunlight was declined to $64 \%$ by the PVC film. This level of light shading was thought to be a common light environment in plastic house, and was provided as a control. At the other two sections, light intensities were more reduced by shade cloth ; covering the house with the combination of PVC film and the shade cloth made of polyethylene fabric produced $24 \%$ (middle shading) and $10 \%$ (deep shading) sunlight conditions, respectively. The bottom halves of the shading fabric and PVC film were left open for air ventilation. Air temperature and relative humidity, for each shading condition inside the plastic house, were monitored by a thermo-hygrometer (CDR-TH1, Sekisuikagaku Co. Ltd., Osaka Japan) under the canopy at $1.5 \mathrm{~m}$ height.

Photosynthetic photon flux density (PPF) at each sunlight condition and in full sun was measured on June 15 1996, with a quantum sensor (LI-190SB, LI-COR Inc., Lincoln, NE) connected to a data logger (21X, Campbell Scientific Inc., Logan, UT). Then the light transmission percentages were determined as compared to PPF at full sunlight with means of 10 replications. 
Under-tree irrigation was conducted weekly by sprinklers to maintain soil water potential $<25 \mathrm{kPa}$ at $30 \mathrm{~cm}$ depth under ground, as monitored by a tensiometer.

Shoot growth, leaf morphology and leaf chlorophyll content. At the start of shading treatment, 10 lateral shoots at each sunlight condition were tagged at the basal point of the upper most leaf. These shoots were produced at $1.5 \mathrm{~m}$ above ground level and all these were fruit-bearing at the basal point. To determine the shoot growth and leaf morphological characteristics, the tagged shoots were removed from trees at the tagged positions on October 2. The shoot length, stem diameter and leaf number of the sampled shoots were determined, and then the inter-node length was calculated. Leaf area was measured by a portable leaf area meter (LI-3000, LI-COR). Thereafter, the sampled shoots were divided into leaves and stems, and they were dried in a draft-oven at $70^{\circ} \mathrm{C}$ for $3 \mathrm{~d}$ to obtain a constant dry weight. After the measurements of leaf and stem dry weight, specific stem length (SSL) and specific leaf area (SLA) were calculated as shoot length and as total leaf area per unit dry weight, respectively.

Twenty weeks after growing under the shading conditions, relative values of chlorophyll contents were determined for leaves which were developed during shading, and those which had already expanded before shading. Such pre- and post-shade leaves were selected from proximal and distal shoot positions to the tagged leaf. Ten leaves were used for pre- or post-shade treatments. The relative values obtained by a portable chlorophyll meter (GM1, Fuji Film Co. Ltd., Tokyo, Japan) were consequently converted into an area-basis chlorophyll content using an equation described by Higuchi et al. (1998a).

Leaf gas exchange. Leaf $A_{\mathrm{C}}$, air temperature $\left(T_{\mathrm{a}}\right)$, leaf temperature $\left(T_{\mathrm{L}}\right)$, leaf-to-air vapor pressure defference $\left(\mathrm{VPD}_{\mathrm{L}}\right)$, transpiration rate $(E)$, and stomatal conductance $\left(g_{\mathrm{s}}\right)$ were measured during midday hours $(1100 \mathrm{~h}-1300 \mathrm{~h})$ on June 15,1996 . The leaves for this measurement were selected from 8-week-old sun-exposed leaves developed at each shading condition on the tagged shoots $1.5 \mathrm{~m}$ above ground level. Additionally, to compare these variables with leaves under full sunlight, a full sunlight condition by removing glass from a glass-house aside the plastic house had been prepared 2 months before this measurement. In the glass-house, 4-year-old 4 'Big Sister' trees were growing. Where, the trees were planted 2 $\mathrm{m}$ intervals and had $3 \mathrm{~m}$ height. We used a portable photosynthetic system (LI-6200, LICOR) to make these measurements. Each measurement was repeated 10 times.

Diurnal changes of $A_{\mathrm{C}}, g_{\mathrm{s}}, E$, water use efficiency (WUE) calculated as $A_{\mathrm{c}} / E, \mathrm{PPF}$, relative humidity $(\mathrm{RH}), \mathrm{VPD}_{\mathrm{L}}$ and $T_{\mathrm{L}}$ were determined for leaves grown under the 3 different shading conditions, by the portable system mentioned above, on July 13 (a clear day). The measurements were started pre-dawn and continued until after sunset, at about 2 -h intervals. The measured leaves were selected from sun-exposed post-shaded fully mature leaves (over 10 replicates) aged 8 weeks on lateral orientated shoots at $1.5 \mathrm{~m}$ above ground level.

The air conditions inside the chamber were controlled as to follow the ambient condition of each light environment.

Leaf water potential. Diurnal changes of leaf water potential were measured for leaves grown at the different shading levels, using a thermocouple psychrometer (SC10A, Decagon Devices Inc., Pullman WA), on July 13. The measurements were started pre-dawn and were continued to after sunset, at about 2-h intervals. Exposed leaves were selected from those produced a few weeks after shading. The leaves sampled from each shading level were immediately put into the psychrometer chambers. After a $3 \mathrm{~h}$ thermal equilibrium period, water potential was determined by dew point measurements.

Fruit production. Hand-pollination was performed from March to May 1996 for every tree of each shading level. The pollinated flowers were tagged with labels to record the date of pollination. Fruits were thinned to adjust leaf/fruit ratio to be $\approx 50$, in June. To determine the growth curve and the growth rate, fruit width and length of randomly selected 
5 fruit of each shading level were measured using a vernier micrometer every 2 weeks after the pollination to the harvest. Fruit was harvested when ripened, thereafter, immediately weighted and the harvest date was recorded. Then, the fruit was kept at room temperature for a week to be softened. Total soluble solid and $\mathrm{pH}$ of the fruit tissue were determined using a refractometer (N-1, Atago Co. Ltd., Tokyo, Japan) and a pH meter (D-21S, Horiba Co. Ltd., Kyoto, Japan), respectively. Randomly selected 27 fruits from each shading condition were used for these measurements.

\section{RESULTS}

\section{Shoot growth, leaf morphology and leaf chlorophyll content}

Shoot length and leaf number at light shading condition (64\% sunlight) were larger than at the other shade levels (Table 1). Inter-node length and specific stem length were increased with shade. Stem diameter and leaf and stem dry weight were greater at light shading condition. Although tissue dry weights were suppressed at deep shading condition (10\% sunlight), stem dry weight was less affected by shading than leaf dry weight. The thinner and larger leaves developed under the heavier shade environments. Single leaf area was increased by heavier shading, although the total leaf area per shoot was reduced. Specific leaf area became larger as shading level increased, indicating that leaves at heavier shade reduced leaf thickness.

Leaf chlorophyll content was increased by low light intensity for pre-shade leaves (Table 2). However, for post-shade leaves, the highest value was observed at middle shading condition (24\% sunlight).

\section{Leaf gas exchange}

Midday $A_{\mathrm{C}}, E$, and $g_{\mathrm{s}}$ were the highest for leaves at $64 \%$ and $24 \%$ sunlight than the other irradiance levels, and there were non-significant differences between these two lighter shading

Table 1 Leaf and shoot growth and morphological characteristics of cherimoya 'Big Sister' at different shading levels under plastic house conditions.

\begin{tabular}{|c|c|c|c|}
\hline \multirow{2}{*}{ Variable } & \multicolumn{3}{|c|}{ Shading levels (\% sunlight $)^{z}$} \\
\hline & Light (64\%) & Middle (24\%) & Deep (10\%) \\
\hline Shoot length $(\mathrm{cm})$ & $64.8 \mathrm{a}$ & $43.5 \mathrm{ab}$ & $24.9 \mathrm{~b}$ \\
\hline Leaf number & $13.3 \mathrm{a}$ & $6.8 \mathrm{~b}$ & $3.6 \mathrm{~b}$ \\
\hline Inter-node length $(\mathrm{cm})$ & $4.84 \mathrm{~b}$ & $5.88 \mathrm{ab}$ & $6.36 \mathrm{a}$ \\
\hline Stem diameter $(\mathrm{mm})$ & $6.65 \mathrm{a}$ & $5.86 \mathrm{ab}$ & $4.23 \mathrm{~b}$ \\
\hline Leaf area/shoot $\left(\mathrm{cm}^{2}\right)$ & $2148 \mathrm{a}$ & $1405 \mathrm{ab}$ & $873 b$ \\
\hline Area/leaf $\left(\mathrm{cm}^{2}\right)$ & $170.9 \mathrm{~b}$ & $198.8 \mathrm{ab}$ & $231.2 \mathrm{a}$ \\
\hline Leaf dry weight (g) & $8.68 \mathrm{a}$ & $4.27 \mathrm{~b}$ & $2.16 \mathrm{~b}$ \\
\hline Stem dry weight (g) & $3 \mathrm{a}$ & $2.35 \mathrm{ab}$ & $0.48 \mathrm{~b}$ \\
\hline Specific stem length $\left(\mathrm{cm} \mathrm{g}^{-1}\right)$ & $20.3 \mathrm{a}$ & $58.1 \mathrm{a}$ & $124.5 \mathrm{~b}$ \\
\hline Specific leaf area $\left(\mathrm{dm}^{2} \mathrm{~g}^{-1}\right)$ & $2.77 \mathrm{~b}$ & $3.31 \mathrm{ab}$ & $3.84 \mathrm{a}$ \\
\hline
\end{tabular}

Shading was started on May 17 and measurements were made on October 2. Data are based on newly developed part of selected shoots after the shading started. Different letters in the same raw indicate significant differences by Duncan's range test at $p<0.05$.

${ }^{z}$ Light shading was under a plastic house of PVC film, middle shading was produced by covering the plastic house of the PVC film with single sheet of polyethylene fabric, and deep shading was provided by double sheets of the polyethylene fabric on the PVC film. 
Table 2 Leaf chlorophyll content of cherimoya 'Big Sister' at different shading levels under plastic house conditions.

\begin{tabular}{lccc}
\hline \multirow{2}{*}{$\begin{array}{c}\text { Leaf chlorophyll }(\mathrm{a}+\mathrm{b}) \\
\text { content }\left(\mathrm{mg} \mathrm{dm}^{-2}\right)\end{array}$} & \multicolumn{3}{c}{ Shading levels (\% sunlight) } \\
\cline { 2 - 4 } & Light $(64 \%)$ & Middle $(24 \%)$ & Deep (10\%) \\
\hline Pre-shade leaf & $2.47 \mathrm{c}$ & $3.29 \mathrm{~b}$ & $3.65 \mathrm{a}$ \\
Post-shade leaf & $3.01 \mathrm{~b}$ & $3.19 \mathrm{a}$ & $2.93 \mathrm{~b}$ \\
\hline
\end{tabular}

Shading was started on May 17 and measurements were made on October 2. Data are means of 20-week-old 10 leaves developed just before and after starting of shade. Different letters in the same raw indicate significant differences by Duncan's range test at $p<0.05$.

${ }^{z}$ Light shading was under a plastic house made of PVC film, middle shading was produced by covering the plastic house of the PVC film with single sheet of polyethylene fabric, and deep shading was provided by double sheets of the polyethylene fabric on the PVC film.

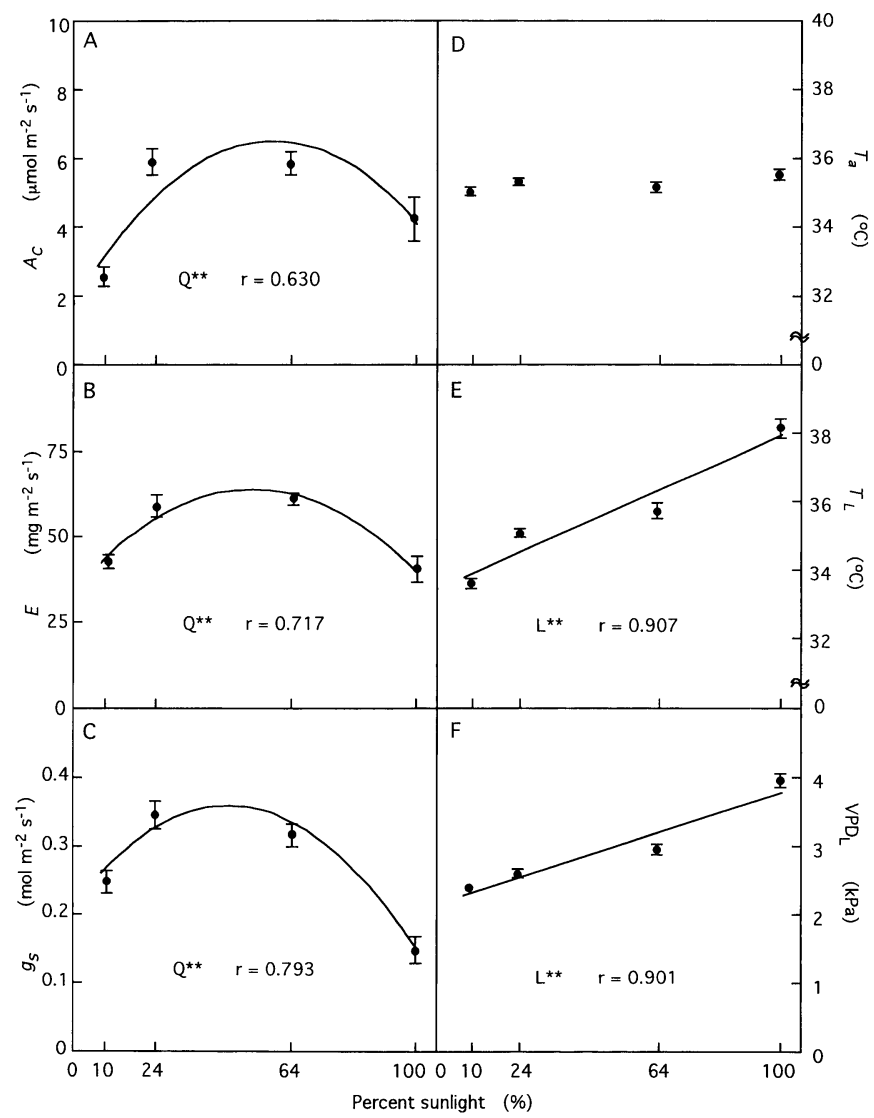

Fig. 1 (A) Leaf $\mathrm{CO}_{2}$ assimilation rate $\left(A_{\mathrm{C}}\right)$, (B) transpiration rate $(E)$, (C) stomatal conductance $\left(g_{\mathrm{s}}\right)$, (D) air temperature $\left(T_{\mathrm{a}}\right)$, (E) leaf temperature $\left(T_{\mathrm{L}}\right)$ and $(\mathrm{F})$ leaf-to-air vapor pressure difference $\left(\mathrm{VPD}_{\mathrm{L}}\right)$ of cherimoya 8-week-old exposed leaves under $10 \%, 24 \%, 64 \%$ and $100 \%$ of sunlight conditions during midday hours $(1100 \mathrm{~h}-1300 \mathrm{~h})$ on June $15,1996$.

Solid lines indicate significant linear $(\mathrm{L})$ or quadratic $(\mathrm{Q})$ correlation at $p<0.01$ with percent sunlight transmission. Each point is a mean of 10 replications and vertical bars represent $\pm \mathrm{SE}$. 
conditions (Fig. 1). Leaves under full sunlight indicated higher $A_{\mathrm{C}}$ than at $10 \%$ sunlight, but exhibited lower $g_{\mathrm{s}}$. At full and $10 \%$ sunlight, $E$ was similar. The shading level linearly affected $T_{\mathrm{L}}$ and $V P D_{\mathrm{L}}$ : the highest $T_{\mathrm{L}}$ and $\mathrm{VPD}_{\mathrm{L}}$ were given for full sunlight.

Diurnal changes in environmental variables and leaf gas exchange were influenced by shading treatment (Fig. 2). Generally, $A_{\mathrm{C}}$ was higher with less shading except for during midday when difference in $A_{\mathrm{C}}$ between $64 \%$ and $24 \%$ sunlight was very small. At $64 \%$ and $24 \%$ sunlight conditions, $A_{\mathrm{C}}$ was relatively higher in the morning. This tendency was pronounced for the lighter environment. Under every shading condition, $g_{\mathrm{s}}$ tended to decrease generally during the daytime. Although the diurnal patterns of $E$ of all treatments were similar to those of $A_{\mathrm{C}}$, differences among the treatments were not as large as those in $A_{\mathrm{C}}$. Thus, WUE at $10 \%$ sunlight during daytime was substantially lower than $24 \%$ and $64 \%$ sunlight plants. At $64 \%$ sunlight condition, $T_{\mathrm{L}}$ for daytime was continuously higher. Increasing trends of $\mathrm{VPD}_{\mathrm{L}}$

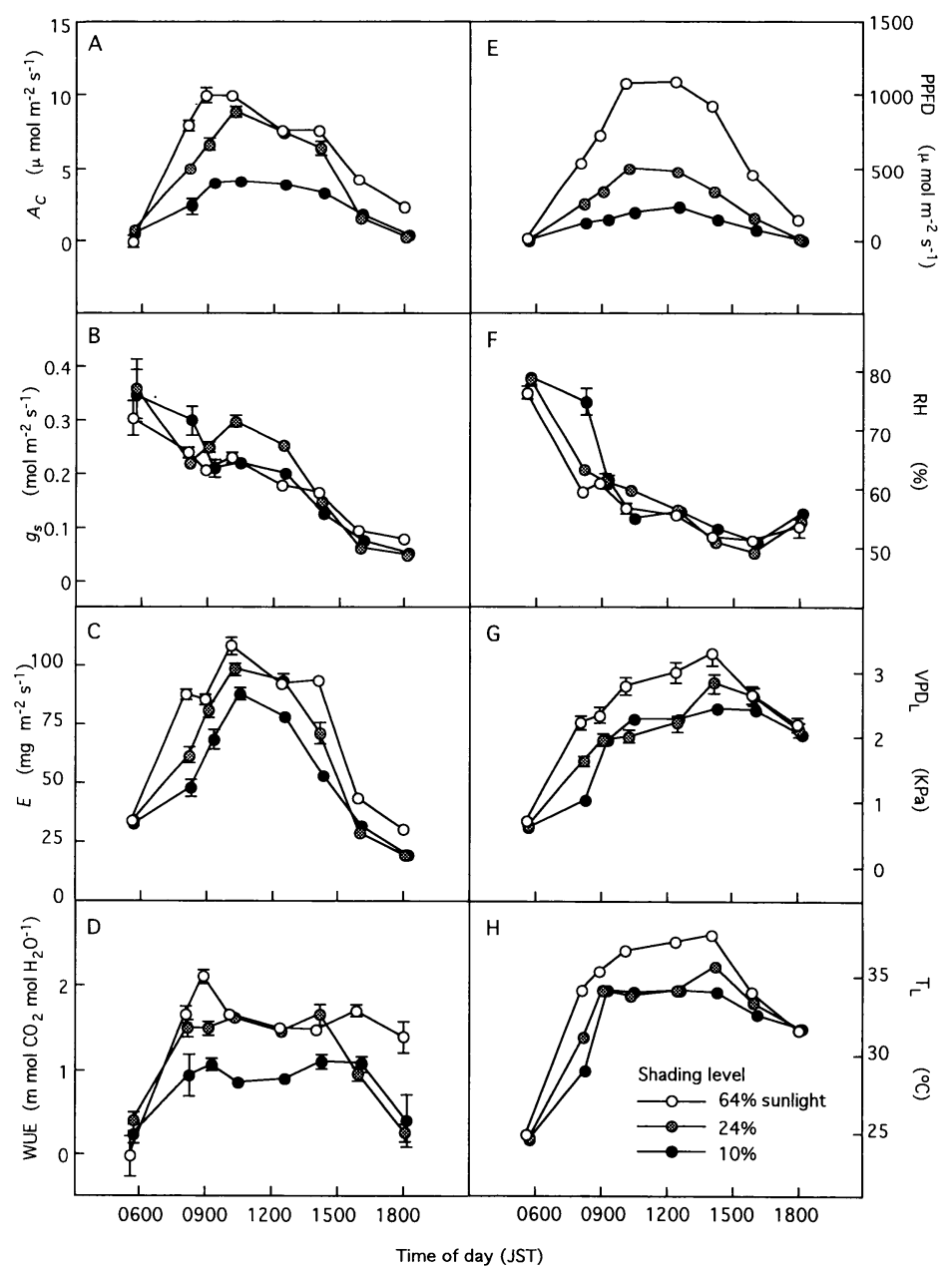

Fig. 2 Diurnal changes of (A) leaf $\mathrm{CO}_{2}$ assimilation rate $\left(A_{\mathrm{C}}\right)$, (B) stomatal conductance $\left(g_{\mathrm{s}}\right)$, (C) transpiration rate $(E)$, (D) water use efficiency (WUE), (E) photosynthetic photon flux density (PPF), (F) relative humidity $(\mathrm{RH}),(\mathrm{G})$ leaf-to-air vapor pressure difference $\left(\mathrm{VPD}_{\mathrm{L}}\right)$, and (H) leaf temperature $\left(T_{\mathrm{L}}\right)$ of cherimoya 8 -week-old exposed leaves grown under different shading conditions on July 13.

Each point is a mean of over 10 replications and vertical bars represent $\pm S E$. 
were observed until $1400 \mathrm{~h}$, under all the conditions, and thereafter $\mathrm{VPD}_{\mathrm{L}}$ decreased. At $64 \%$ sunlight, the highest $\mathrm{VPD}_{\mathrm{L}}$ was continued for $0800 \mathrm{~h}-1400 \mathrm{~h}$. There was non-significant difference between $24 \%$ and $10 \%$ sunlight.

\section{Leaf water potential}

The leaves exposed to lower light intensities maintained a higher leaf water potential throughout the daytime (Fig. 3). Leaves under each condition showed reducing leaf water potential to $1400 \mathrm{~h}$, with some fluctuation. The lowest values were at around $1400 \mathrm{~h}$, and then the water potentials were recovered towards the night.

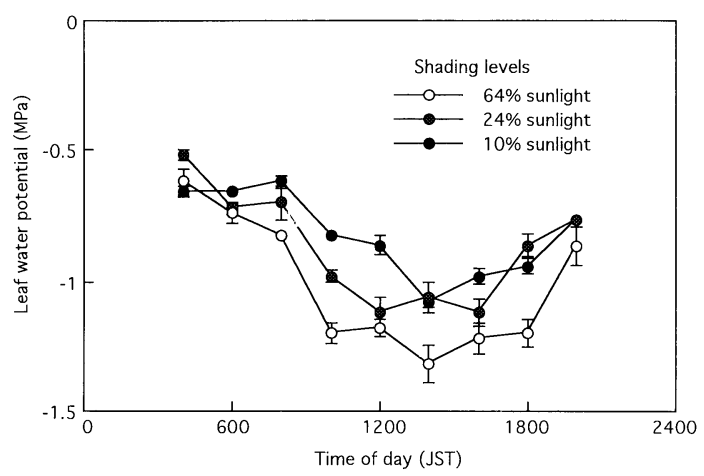

Fig. 3 Diurnal changes of leaf water potential as measured by a dew point psychrometer on August 31 . Exposed leaves were sampled from cherimoya trees grown under different shading $(64 \%, 24 \%$, and $10 \%$ sunlight) conditions. Each point is a mean of 3 replications and vertical bars represent \pm SE.

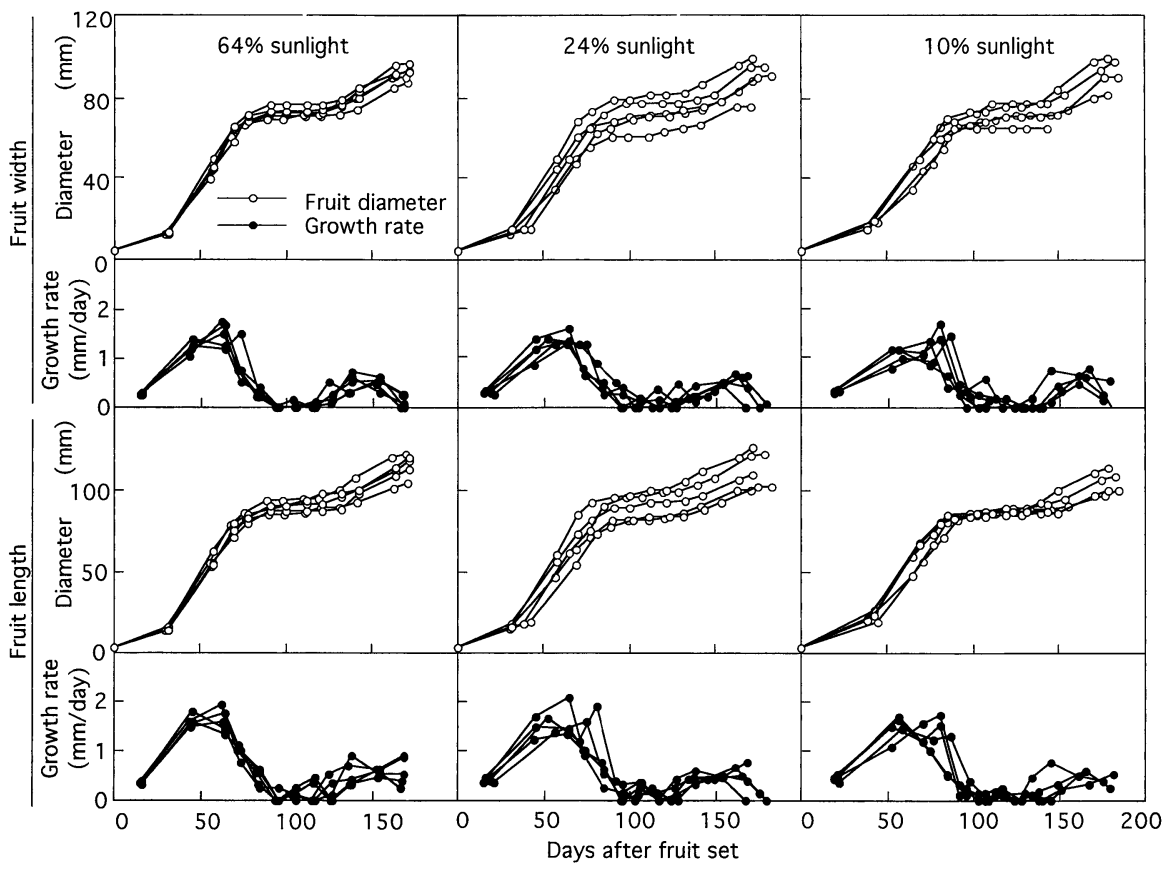

Fig. 4 Fruit growth curves and growth rates of cherimoya fruit grown under different shading (64\%, 24\%, and $10 \%$ sunlight) conditions. 
Table 3 Weight, quality, and days to harvest of 'Big Sister' cherimoya fruit produced under different shading levels.

\begin{tabular}{|c|c|c|c|}
\hline \multirow{2}{*}{ Variables } & \multicolumn{3}{|c|}{ Shading levels (\% sunlight $)^{z}$} \\
\hline & Light (64\%) & Middle (24\%) & Deep (10\%) \\
\hline Fruit weight (g) & $618.7 \mathrm{a}$ & $528.9 \mathrm{ab}$ & $496.3 \mathrm{~b}$ \\
\hline Brix & $17.8 \mathrm{a}$ & $16.0 \mathrm{~b}$ & $15.0 \mathrm{c}$ \\
\hline $\mathrm{pH}$ & $4.9 \mathrm{~b}$ & $5.0 \mathrm{~b}$ & $5.4 \mathrm{a}$ \\
\hline Days to harvest & $194.7 \mathrm{a}$ & $207.1 \mathrm{~b}$ & $226.9 \mathrm{c}$ \\
\hline Date of pollination & Mar. 26 to Apr. 30 & Mar. 30 to Apr. 23 & Apr. 1 to May. 9 \\
\hline Date of harvest & Sept. 29 to Dec. 19 & Sept. 29 to Dec. 16 & Oct. 18 to Dec. 6 \\
\hline
\end{tabular}

\section{Fruit production}

The harvest was delayed as the shading increased. The pattern of fruit growth curve was similar for each shading level, while the growth suspended period was extended under deeper shading (Fig. 4). Fruit size and quality were lower at deeper shading conditions (Table 3). Fruit weight and total soluble solid linearly decreased as the shading increased. Fruit from deep shade showed the highest $\mathrm{pH}$, indicating lowest content of acids.

\section{DISCUSSION}

Although a green-house is indispensable for cherimoya cultivation in Japan, summer temperatures often exceed the optimal range. The attempt to reduce irradiance was discussed to ease such severe environmental conditions during summer. Inside the house without any additional shading, fruit productivity and vegetative growth were more than at the other shading conditions. Leaves at light shading performed higher $A_{\mathrm{C}}$ than those outside the house. A slight shading by plastic film would be advantageous for $A_{\mathrm{C}}$ under such a condition like summer in Japan. At the light shading condition of the current experiment, sunburn and shrink of leaves on tall branches, which might be caused by complex factors of strong irradiance and heated air lying right under the roof, scarcely affected on cherimoya productivity. The film of the house, which we used in the present experiment, was renewed a year before the experiment, and a stale film suggested to be qualified to throw adequate shade. Accordingly, another sheet to make deeper shade might not be beneficial. It is difficult to cultivate cherimoya outside in Japanese weather conditions, so that, we conducted the examination without cherimoya trees growing under full sunlight.

Plants are capable of adaptation to their light environmental conditions (Berry, 1975). But the range of the adaptability is varied for each plant. Shading decreased shoot length, leaf number, stem diameter, and increased area per leaf in cherimoya. As shading increased, leaves became thinner and larger, resulting in a higher specific leaf area. Stems grown in the lower light were shorter and slender, but had the longer inter-node length, and larger specific stem length. Similar morphological responses were noted for other tropical fruit trees such as carambola (Marler et al., 1994) and mangosteen (Wiebel et al., 1994). This modification to thinner and larger leaves is a common adaptation to low irradiance (Fitter and Hay, 1981; Kozlowski and Pallardy, 1997). This adaptation might be a plant strategy to maximize light interception, and in the greater specific stem length and specific leaf area could explain it. 
Cherimoya leaf chlorophyll content on the basis of unit area generally indicated a tendency of a little increase with shade, except for post-shade leaves at $10 \%$ sunlight. The post-shade leaves did not show significant linear increase of chlorophyll content with shade. The increasing tendency of chlorophyll content might be an acclimation to low light environment to enhance the light use efficiency, although this acclimation mechanism was not strongly observed for cherimoya. However, The slight acclimation does not necessarily imply low shade tolerance. Wiebel et al. (1994) reported no significant differences in leaf chlorophyll content for mangosteen grown in $20 \%$ to $80 \%$ sunlight levels. For shade-tolerant trees such as mangosteen, leaf chlorophyll content did not significantly affected by irradiance. Whereas for mango leaves, chlorophyll content increased as shade increased (Schaffer and Gaye, 1989). Citrus leaves grown under heavy shade decreased maximum assimilation rate (Syvertsen, 1984) and decreased the thickness but increased chlorophyll content (Syvertsen and Smith, 1984). The cherimoya adaptation of leaf chlorophyll content to irradiance level probably lies between mangosteen and mango or citrus.

High light intensity caused high $T_{\mathrm{L}}$, which was assumed a major factor increasing $\mathrm{VPD}_{\mathrm{L}}$. A stomatal closure also caused high $\mathrm{VPD}_{\mathrm{L}}$. High $\mathrm{VPD}_{\mathrm{L}}$ tends to decrease $g_{\mathrm{s}}$ and $A_{\mathrm{C}}$ again (Khairi and Hall, 1976 ; Farquhar and Sharkey, 1982 ; Higgins et al., 1992). In this experiment, the $\mathrm{VPD}_{\mathrm{L}}$ of cherimoya is suggested to rise easily and to lead to stomatal closure under high irradiance. Decline in $g_{\mathrm{s}}$ throughout daytime was associated with increasing $\mathrm{VPD}_{\mathrm{L}}$. George et al. (1990) noted that the midday suppression in $g_{\mathrm{s}}$ for atemoya recovered with increasing relative humidity after $1600 \mathrm{~h}$. Decreased $g_{\mathrm{s}}$ during midday even for non-irrigated macadamia leaf began to increase at $1600 \mathrm{~h}$ (Lloyd et al., 1991). Whereas for cherimoya leaves under various shading levels, consistent decline in $g_{\mathrm{s}}$ until after sunset was observed. The diurnal trend of $g_{\mathrm{s}}$ reduction in cherimoya was similar to that of coffee (Gutierrez et al., 1994) and mangosteen (Wiebel et al., 1994). Fanjul et al. (1985) reported that $g_{\mathrm{s}}$ of coffee continued to be restrained over afternoon on the day when $\mathrm{VPD}_{\mathrm{L}}$ increased to $0.8 \mathrm{KPa}$. The stomata of cherimoya is suggested to be more sensitive to close and insensitive to open when exposed to midday atmospheric drought condition as compared to atemoya, macadamia, and citrus.

Water stress was closely related to midday acceleration of $\mathrm{VPD}_{\mathrm{L}}$ with $A_{\mathrm{C}}$ suppression for citrus (Brakke and Allen, 1995). It is well known that water stress causes stomatal closure. The decline of leaf water potential during daytime in cherimoya indicated leaf water stress. The daytime reduction was more pronounced under less shaded conditions. The lowered $A_{\mathrm{C}}$ during midday might be thus affected by stomatal closure with water stress. Decreased $g_{\mathrm{s}}$ in this situation is supposed to be a water conserving mechanism at the expense of $A_{\mathrm{C}}$. This mechanism is assumed to interfere with light use efficiency of $64 \%$ sunlight during midday. This assumption can be explained by the little difference in daytime WUE under $64 \%$ and $24 \%$ sunlight treatments.

Shading was effective for decreasing leaf temperature, easing of water stress. The effect of shading varied $24 \%$ to $64 \%$ sunlight on increasing $g_{\mathrm{s}}$ may attribute to increase $A_{\mathrm{c}}$, compensating for the effect of low light intensity. Thus, light shading with coarse texture will be recommendable to increase photosynthetic production during hot season. Under cool conditions, however, shading may not be needed expressly, as $\mathrm{VPD}_{\mathrm{L}}$ could hardly exceed the range where the $g_{\mathrm{s}}$ reduction suppresses $A_{\mathrm{c}}$. The heavy shade produced by the combination of polyethylene fabric and PVC film was unfavorable for cherimoya fruit production. A slight shading of just PVC film or that combined with coarse texture like wind protection net which defends plastic house against typhoon damage providing $50-70 \%$ sunlight would be recommendable. 


\section{REFERENCES}

Berry, J. A. 1975. Adaptation of photosynthetic responses to stress. Science 188 : 644-650.

Brakke, M., Allen, L. H. Jr. 1995. Gas exchange of citrus seedlings at different temperatures, vaporpressure deficits, and soil water contents. J. Am. Soc. Hortic. Sci. 120 : 497-504.

Fanjul, L., Arreola, R. R., Mendez, C. M. P. 1985. Stomatal responses to environmental variables in shade and sun grown coffee (Coffea arabica) plants in Mexico. Exp. Agric. 21 : 249-258.

Farquhar, G. D., Sharkey, T. D. 1982. Stomatal conductance and photosynthesis. Annu. Rev. Plant Physiol. 33 : 317-345.

Fitter, A. H., Hay, R. K. M. 1981. Environmental Physiology of Plants. Academic Press, New York, pp 423.

George, A. P., Nissen, R. J. 1992. Annona. In "Plant Resources of South-East Asia. 2 : Edible Fruit and Nuts" (ed. by Verheij, E. W. M., Coronel, R. E.). Prosea, Bogor, p 71-75.

George, A. P., Nissen, R. J., Howitt, C. 1990. Effects of environmental variables and crop load on leaf conductance of custard apple (Annona cherimola $\times$ Annona squamosa) 'African Pride.' Sci. Hortic. 45 : 137-148.

Gutierrez, M. V., Meinzer, F. C., Grantz, D. A. 1994. Regulation of transpiration in coffee hedgerows : covariation of environmental variables and apparent responses of stomata to wind and humidity. Plant Cell Environ. 17 : 1305-1313.

Higgins, S. S., Larsen, F. E., Bendel, R. B., Ladamaker, G. K., Bassman, J. H., Bidlake, W. R., Alwir, A. 1992. Comparative gas exchange characteristics of potted, glasshouse-grown almond, apple, fig, grape, olive, peach, and Asian pear. Sci. Hortic. 52 : 313-329.

Higuchi, H., Sakuratani, T., Utsunomiya, N. 1999. Photosynthesis, leaf morphology, and shoot growth as affected by temperatures in cherimoya (Annona cherimola Mill.) trees. Sci. Hortic. 80 : 91-104.

Higuchi, H., Utsunomiya, N., Sakuratani, T. 1998a. Effects of temperature on growth, dry matter production and $\mathrm{CO}_{2}$ assimilation in cherimoya (Annona cherimola Mill.) and sugar apple (Annona squamosa L.) seedlings. Sci. Hortic. 73 : 89-97.

Higuchi, H., Utsunomiya, N., Sakuratani, T. 1998b. High temperature effects on cherimoya fruit set, growth and development under greenhouse conditions. Sci. Hortic. $77: 23-31$.

Khairi, M. M. A., Hall, A. E. 1976. Temperature and humidity effects on net photosynthesis and transpiration of citrus. Physiol. Plant. 36: 29-34.

Kozlowski, T. T., Pallardy, S. G. 1997. Physiology of Woody Plants. Academic Press, New York, pp 411.

Lloyd, J., Trochoulias, T., Ensbey, R. 1991. Stomatal responses and whole-tree hydraulic conductivity of orchard Macadamia integrifolia under irrigated and non-irrigated conditions. Austr. J. Plant Physiol. $18: 661-672$.

Marler, T. E., Schaffer, B., Crane, J. H. 1994. Developmental light level affects growth, morphology, and leaf physiology of young carambola trees. J. Am. Soc. Hortic. Sci. 119 : 711-718.

Schaffer, B., Gaye, G. O. 1989. Gas exchange, chloraphyll and nitrogen content of mango leaves as affected by light environment. HortScience 24 : 507-509.

Syvertsen, J. P. 1984. Light acclimation in citrus leaves. II. $\mathrm{CO}_{2}$ assimilation and light, water, and nitrogen use efficiency. J. Am. Soc. Hortic. Sci. 109: 812-817.

Syvertsen, J. P., Smith J. L. 1984. Light acclimation in citrus leaves. I. Changes in physical characteristics, chlorophyll, and nitrogen content. J. Am. Soc. Hortic. Sci. 109 : 807-812.

Utsunomiya, N., Higuchi, H. 1996. Effects of irradiance level on the growth and photosynthesis of cherimoya, sugar apple and soursop seedlings. Environ. Control in Biol. 34 : 201-207.

Wiebel, J., Chacko, E. K., Downton, W. J. S., Ludders, P. 1994. Influence of irradiance on photosynthesis, morphology and growth of mangosteen (Garcinia mangostana L.) seedlings. Tree Physiol. 14 : 263-274. 


\section{〈和文抄録〉}

\section{遮光条件下におけるチェリモヤの葉内クロロフィル含量・葉形態・新梢生長・ 葉のガス交換および果実生産の日本におけるビニルハウス内での反応}

\section{桶口浩和・米本仁 巳 ${ }^{*, 1}$ ・宇都宮直樹**・桜谷哲夫}

京都大学農学研究科, * 和歌山県果樹園芸試験場, ${ }^{* *}$ 近畿大学農学部

${ }^{1}$ 現在：和歌山県農林水産総合技術センター山村産業試験場

チェリモヤ (Annona cherimola Mill.) のハウス栽培では, 夏期の高温が生産性低下の問題となっ ている。 そこで, 遮光によって生産性が高まるかどうか検討するため, ビニルハウス内で栽植して いた 6 年生チェリモヤ品種 Big Sister に, 以下に示す 3 段階の異なる遮光処理, すなわち軽遮光区 として通常のビニルハウス内の条件, ハウスのビニルと寒冷紗を組み合わせた中遮光区, ビニルに 2 重の寒冷紗をかぶせた重遮光区を設けた。新梢長, 新梢径, 葉数および総葉面積は遮光がきつく なるにしたがい低下したが, 節間長と 1 葉あたりの葉面積は増加した. 葉のクロロフィル含量は重 遮光区で増加した。軽遮光区と中遮光区では高い光合成速度と気孔コンダクタンスが観察された。 光が強くなると, 葉温が上昇して葉面飽差が増大し，ガス交換速度は低下した。軽遮光区では終日 高い光合成速度が観察されたが, 日中の数時間は気孔の閉鎖と水ポテンシャルの低下が見られ, 光 合成速度は低下した。 中遮光区と重遮光区では果実重と果実品質が低下し, 収穫期が遅れた。ビニ ルハウスで寒冷紗をかけることによる強い遮光条件はチェリモヤの生産性を低下させることが分 かった５0７0\%の遮光条件がチェリモヤ栽培にとって好適な光環境であろうと思われた. 